\title{
Preliminary Data on the In Vitro Effect of Copper- Based Compounds on Aerobic Bacterial Microflora Isolated from Sheep Footrot
}

\author{
Flore CHIRILA $\breve{A}^{1}$, George Cosmin NADĂŞ*1, Sorin RĂPUNTEAN ${ }^{1}$, Cosmina Maria BOUARI $^{1}$, Ioana MATEI ${ }^{1}$, \\ Cristina FELECAN ${ }^{2}$, Octavia NEGREA ${ }^{1}$, Zamfir MARCHIŞ ${ }^{2}$, Vasile MICLĂUŞ ${ }^{3}$, Nicodim Iosif FIȚ $^{1}$ \\ ${ }^{1}$ University of Agricultural Sciences and Veterinary Medicine Cluj-Napoca, Faculty of Veterinary Medicine, \\ 3-5 Mănăştur Street, 400372, Cluj-Napoca, Romania \\ ${ }^{2}$ University of Agricultural Sciences and Veterinary Medicine Cluj-Napoca, Faculty of Animal Science and \\ Biotechnologies, 3-5 Mănăștur Street, 400372, Cluj-Napoca, Romania \\ ${ }^{3}$ Babes-Bolyai University Cluj-Napoca, Faculty of Chemistry and Chemical Engineering \\ Arany Janos Str. no. 11, RO-400028, Cluj Napoca , Romania \\ *corresponding author: gnadas@usamvcluj.ro
}

Bulletin UASVM Veterinary Medicine 75(1)/2018

Print ISSN 1843-5270; Electronic ISSN 1843-5378

doi:10.15835/buasvmcn-vm:005317

\begin{abstract}
Contagious sheep footrot is an infectious disease with chronic evolution, usually enzootic, characterized by necrotic or necrotic-purulent inflammation of the soft tissues of the hoof, which causes partial or total detachment of the horn. Cu-based products represented by (I) 1-hydroxyquinoline $+\mathrm{Cu}$ on $5 \%$ hydroxyapatite, (II) 2 Hydroxyquinoline $+\mathrm{Cu}+\mathrm{NO}_{3}$ on $5 \%$ Hydroxyapatite and (III) 3 Nitrohydroxyquinoline $+\mathrm{Cu}$ on $5 \%$ Hydroxyapatite were conditioned in aqueous suspension in a volume of $100 \mathrm{ml}, \mathrm{pH} 6,0-6,4$. The products were placed into wells, $20 \mu \mathrm{L} /$ well, along with $0.5 \%$ copper sulphate solution ( $\mathrm{Cu}$ control) and Enroxil and Oxitetracycline (control for antibiotics).

The results demonstrated that 7 of the samples (58.33\%) are sensitive to the product I, 6 samples (50\%) to the product III, 4 samples (33.33\%) to the product 2 and the $0.5 \%$ Copper sulphate solution only has a bacteriostatic effect. In comparison to the two antibiotics, 9 samples (75\%) are sensitive to enrofloxacin and only 5 samples (41.66 \%) to oxytetracycline. Regarding the associations of microorganisms in the samples with resistance, we have found that these are represented by the most common germs of genus Bacillus, Corynebacterium and Gram negative bacteria, and rarer associations with Micrococcus and Staphylococcus.
\end{abstract}

Keywords: cooper, sheep, foot rot, aerobic bacteria.

\section{Introduction}

Contagious sheep footrot is an infectious disease with chronic evolution, usually enzootic, characterized by necrotic or necrotic-purulent inflammation of the soft tissues of the hoof, which causes partial or total detachment of the horn (Bercea et al., 1981). This condition is also known as contagious footrot. It is found throughout the year but with a higher frequency in rainy seasons (Negrea, 2007).
Two species of synergistically acting anaerobic bacteria, Dichelobacter nodosus (Bacteroides) and Fusobacterium necrophorum are involved in the etiology of this disease (Witcomb et al., 2014). In addition to these species, others that may act synergistically or as complication factors are: Trueperella, (Archanobacterium), (Actinomyces), pyogenes, Spirocheta penortha, Clostridium perfringens.. Often from the lesions (especially in small ruminants) Most commonly, germs such as 
Table 1. Number of samples collected from six sheep flocks

\begin{tabular}{cccc}
\hline Nr. crt. & Samples & Flock & Sheep number \\
\hline 1. & $1-4$ & 1 & 530 sheep \\
\hline 2. & $5-9$ & 2 & 280 sheep \\
\hline 3. & $10-20$ & 3 & 780 sheep \\
\hline 4. & $21-27$ & 4 & 214 sheep \\
\hline 5. & $28-32$ & 5 & 890 sheep \\
\hline 6. & $33-36$ & 6 & 420 sheep \\
\hline
\end{tabular}

Table 2. Percentages of sheep footrot morbidity in six sheep flock

\begin{tabular}{ccccc}
\hline Nr. & Flock & Sick animals & Total sheep & Percentage of morbidity \\
\hline 1 & 1 & 4 & 530 & 0,75 \\
\hline 2 & 2 & 5 & 280 & 1,78 \\
\hline 3 & 3 & 11 & 780 & 1,41 \\
\hline 4 & 4 & 7 & 214 & 3,27 \\
\hline 5 & 5 & 5 & 890 & 0,56 \\
\hline 6 & 6 & 4 & 420 & 0,95 \\
\hline & Total & 36 & 3114 & 1,16 \\
\hline
\end{tabular}

Fusobacterium necrophorum, Arcanobacterium pyogenes, Alistipes putredinis, Prevotella spp., Peptostreptococcus anaerobius, Megasphaera elsdenii, Leptotrichia buccalis, Clostridium perfringens, Staphylococcus spp. and others are isolated. An important role is attributed to different species of the genus Treponema (Rasmussen et al., 2012).

\section{Materials and methods}

The microorganisms used in the present study were isolated from 36 samples represented by swabs with secretions from sheep suffering from hoof lesions from 6 different flocks, detailed in table 1.

Cultural examination was performed using classical microbiological methods such as glucose agar, Mueller-Hinton agar and blood agar inoculations. $\mathrm{Cu}$-based products represented by 1 -hydroxyquinoline $+\mathrm{Cu}$ on $5 \%$ hydroxyapatite, 2 -Hydroxyquinoline $+\mathrm{Cu}+\mathrm{NO}_{3}$ on $5 \%$ Hydroxyapatite and 3 -Nitrohydroxyquinoline $+\mathrm{Cu}$ on $5 \%$ Hydroxyapatite were conditioned in aqueous suspension in a volume of $100 \mathrm{~mL}, \mathrm{pH} \mathrm{6,0-6,4}$.

The tests were performed onto mixture of microorganisms isolated from the first 12 samples, on Mueller-Hinton agar, using diffusimethrical technique for suspectibility testing. The products were placed into wells, $20 \mu \mathrm{L} /$ well, along with $0.5 \%$ copper sulphate solution (copper control) and Enroxil and Oxitetracycline (control for antibiotics).

\section{Results and discussions}

Ratio between the number of individuals found sick and the number of individuals in the flock, resulted in the percentage of morbidity, shown in Table 2.

This indicator vary between 0,56 and 3,27. Following the bacteriological examination, based on the morphological and cultural characteristics of isolated bacteria from the 36 samples collected, the following genera and groups of microorganisms were identified, as presented in Table 3.

From the analysis of data presented in Table 3 it is confirmed that a polymorphic flora participates in the etiology of the footrot which by its enzymatic equipment produces sensitization of the skin from the interdigital space or other types of lesions that create favorable conditions for colonization with the anaerobic microflora.

The results of the antimicrobial effect of the three hydroxyquinoline-based products added with $\mathrm{Cu}$ and hydroxyapatite on the microflora isolated from sheep footrot are shown in Fig. 1, 2 and Table 4.

From the analysis of the data presented in Table 4 it is found that 7 of the samples $(58.33$ $\%)$ are sensitive to the product I, 6 samples (50 $\%)$ to the product III, 4 samples (33.33 b\%) to the product 2 and the $0.5 \% \mathrm{Cu}$ sulphate solution only has a bacteriostatic effect. In comparison to the two antibiotics, 9 samples (75\%) are sensitive 
Table 3. Genera and group of microorganisms isolated from the samples of sheep footrot lesions

\begin{tabular}{|c|c|c|c|c|}
\hline Nr. & & $\overline{\text { Bac }}$ & isolated from lesions & \\
\hline 1 & Staphylococcus & Bacillus & Corynebacterium & \\
\hline 2 & & & Corynebacterium & Micrococcus \\
\hline 3 & & & & Micrococcus \\
\hline 4 & & Bacillus & & \\
\hline 5 & & Bacillus & Corynebacterium & Gram - rods \\
\hline 6 & & Bacillus & & $\begin{array}{l}\text { Micrococci, Gram - rods } \\
\text {, streptococci }\end{array}$ \\
\hline 7 & & Bacillus & & \\
\hline 8 & & Bacillus & Corynebacterium & Gram - rods, cocci \\
\hline 9 & & Bacillus & & Gram - rods \\
\hline 10 & Staphylococcus & Bacillus & & Gram - rods \\
\hline 11 & & & & Micrococcus, Gram - rods \\
\hline 12 & & & & Gram - rods \\
\hline 13 & Staphylococcus & & Corynebacterium & Gram - rods, streptococci \\
\hline 14 & Staphylococcus & & Corynebacterium & Gram - rods \\
\hline 15 & Staphylococcus & & Corynebacterium & Streptococcus \\
\hline 16 & & B. licheniformis & Corynebacterium & \\
\hline 17 & Staphylococcus & & & \\
\hline 18 & Staphylococcus & B. licheniformis & & \\
\hline 19 & Staphylococcus & & Corynebacterium & \\
\hline 20 & & Bacillus & & Micrococcus \\
\hline 21 & Staphylococcus & & Corynebacterium & \\
\hline 22 & & & Corynebacterium & \\
\hline 23 & Staphylococcus & & & rods \\
\hline 24 & & Bacillus & & cocci \\
\hline 25 & Staphylococcus & & & \\
\hline 26 & Staphylococcus & B. licheniformis & & \\
\hline 27 & & Bacillus & Corynebacterium & \\
\hline 28 & Staphylococcus & & & \\
\hline 29 & Staphylococcus & & & Streptococcus, Gram - rods \\
\hline 30 & Staphylococcus & & & rods \\
\hline 31 & Staphylococcus & & & \\
\hline 32 & Staphylococcus & & & \\
\hline 33 & Staphylococcus & Bacillus & & Streptococcus \\
\hline 34 & Staphylococcus & Bacillus & Corynebacterium & \\
\hline 35 & Staphylococcus & Bacillus & Corynebacterium & \\
\hline 36 & Staphylococcus & Bacillus & Corynebacterium & \\
\hline
\end{tabular}

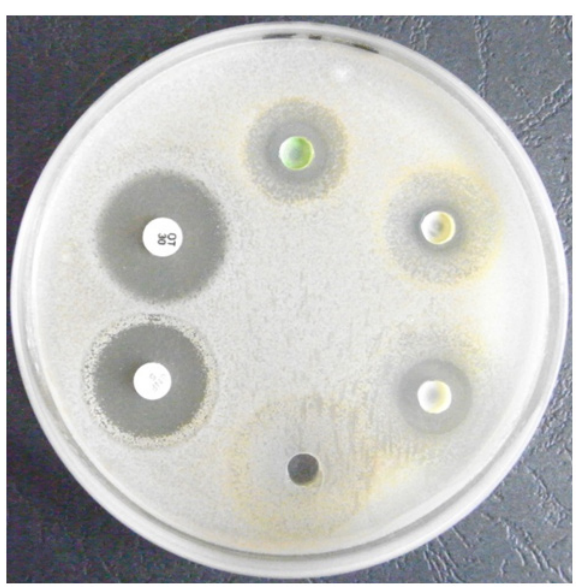

Figure 1. The susceptibility of sample nr. 3 to $\mathrm{Cu}-$ based products and two wide-spectrum antibiotics

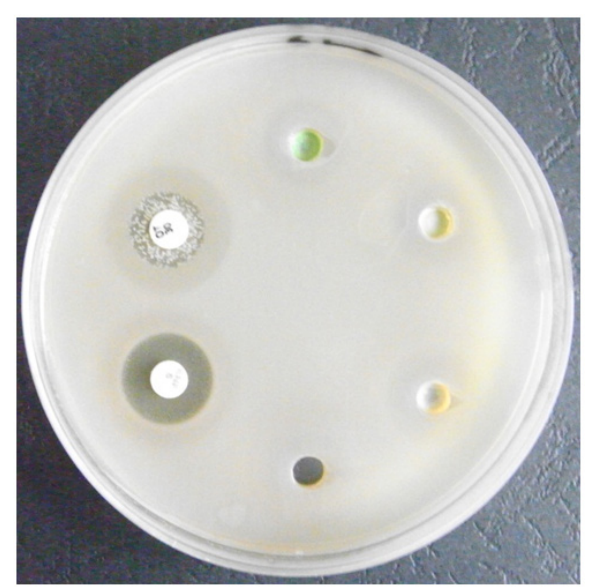

Figure 2. Total resistance of sample 6 to $\mathrm{Cu}$-based products and two wide-spectrum antibiotics 
Tabel 4. The susceptibility of pathogens isolated from sheep footrot samples lesiond to $\mathrm{Cu}$ based products and two wide-spectrum antibiotics

\begin{tabular}{cccccccc}
\hline Nr. & Sample & 1 & 2 & 3 & CuSO4 sol. 0,5 \% & ENF $_{5}$ & OT $_{30}$ \\
\hline 1 & 1 & 9.21 & 9.03 & 11.33 & Bacteriostatic & 21.15 & $\mathrm{R}$ \\
\hline 2 & 2 & $8.95 \mathrm{RC}$ & $7.23 \mathrm{RC}$ & $10.08 \mathrm{RC}$ & Bacteriostatic & 14.32 & $25.03 \mathrm{RC}$ \\
\hline 3 & 3 & 10,04 & 8.75 & 12.41 & Bacteriostatic & 18.27 & 19.72 \\
\hline 4 & 4 & 12.12 & 10.84 & 13.33 & Bacteriostatic & 23,84 & $14.37 \mathrm{RC}$ \\
\hline 5 & 5 & $10.76 \mathrm{RC}$ & $9.88 \mathrm{RC}$ & $14.42 \mathrm{RC}$ & Bacteriostatic & $20.88 \mathrm{RC}$ & $\mathrm{R}$ \\
\hline 6 & 6 & $\mathrm{R}$ & $\mathrm{R}$ & $\mathrm{R}$ & $\mathrm{R}$ & $14.65 \mathrm{RC}$ & $12.39 \mathrm{RC}$ \\
\hline 7 & 7 & 9.87 & 7.64 & 10.89 & Bacteriostatic & 24.15 & 14.31 \\
\hline 8 & 9 & 10.72 & $8.97 \mathrm{RC}$ & $12.62 \mathrm{RC}$ & Bacteriostatic & 24.52 & 22.88 \\
\hline 9 & 10 & $\mathrm{R}$ & $\mathrm{R}$ & 8.48 & 12.53 & 20.30 & 26.83 \\
\hline 10 & 11 & 12.36 & $\mathrm{R}$ & $\mathrm{R}$ & $\mathrm{R}$ & $23.69 \mathrm{RC}$ & $\mathrm{R}$ \\
\hline 11 & 12 & $12.69 \mathrm{CR}$ & $10.78 \mathrm{RC}$ & $14.58 \mathrm{RC}$ & Bacteriostatic & 19.77 & $\mathrm{R}$ \\
\hline 12 & 13 & 12.01 & $13.95 \mathrm{MS}$ & 10.91 & Bacteriostatic & 19.96 & 21.91 \\
\hline & Susceptible & $58.33 \%$ & $33.33 \%$ & $50 \%$ & & $75 \%$ & $41.66 \%$ \\
\hline
\end{tabular}

Legend: 1 - hydroxyquinoline + Cu on $5 \%$ hydroxyapatite; 2 Hydroxyquinoline $+\mathrm{Cu}+\mathrm{NO}_{3}$ on $5 \%$ Hydroxyapatite; 3 -

Nitrohydroxyquinoline $+\mathrm{Cu}$ on $5 \%$ Hydroxyapatite, $\mathrm{ENF}_{5}$-enrofloxacin, $\mathrm{OT}_{30}$ - oxytetracycline. RC - resistant colonies, $\mathrm{R}-$ resistente, MS - moderate susceptibility.

to enrofloxacin and only 5 samples $(41.66 \%)$ to oxytetracycline. Regarding the associations of microorganisms in the samples with resistance, we have found that these are represented by the most common germs of genus Bacillus, Corynebacterium and Gram negative bacteria, and rarer associations with Micrococcus and Staphylococcus.

Hydroxyapatite associated with metal ions (Ag, $\mathrm{Cu}_{2}, \mathrm{Zn}_{2}$ ) has a good antimicrobial effect (Kim et al., 1998). The nHAp-Cu/PEG product has demonstrated a good antibacterial effect in implants and regenerative medicine (Sahithi et al., 2010). In veterinary medicine, copper is used in various formulations to prepare baths to combat underlying diseases, especially in cattle and sheep, or various preparations in the form of a gel or solution for topical applications. [Copper. www. umm.edu/health/medical].

Moreover, the association of hydroxyapatite with tetracycline or ciprofloxacin against $S$. aureus and E. coli strains is increased (Predoi, 2016). The silver doped hydroxyapatite thin films antimicrobial effect was increased against $E$. coli and S. aureus after $24 \mathrm{~h}$ (Iconaru, 2014).

Acknowledgments. This research did not receive any specific grant from funding agencies in the public, commercial, or not-for-profit sectors.

\section{References}

1. Ciobanu CS, Iconaru SL, Le Coustumer P, Constantin LV, Predoi D (2012). Antibacterial activity of silver-doped hydroxyapatite nanoparticles against gram-positive and gram-negative bacteria. Nanoscale Research Letters, 7: 324.
2. Iconaru SL, Chapon P, Le Coustumer P, Predoi D (2014). Antimicrobial Activity of Thin Solid Films of Silver Doped Hydroxyapatite Prepared by Sol-Gel Method. Hindawi Publishing Corporation, 2014: ID 165351.

3. Negrea 0 (2007). Aspecte privind incidenta afectiunilor podale la ovine. Agricultura - Stiință și practică, 1-2: 6162.

4. Pal S, Tak YK, Song JM (2007). Does the antibacterial activity of silver nanoparticles depend on the shape of the nanoparticle? A study of the gram-negative bacterium Escherichia coli. Applied and Environmental Microbiology, 73: 1712-1720.

5. Predoi D, Popa CL, Chapon P, Groza A, Iconaru SL (2016). Evaluation of the Antimicrobial Activity of Different Antibiotics Enhanced with Silver-Doped Hydroxyapatite Thin Films. Materials, 9: E778.

6. Rasmussen M, Capion N, Klitgaard K, Rogodo T, Fieldaas T, Boye M, Jensen TK (2012). Bovine digital dermatitis: posible pathogenic consortium consisting of Dichelobacter nodosus and multiple Treponema species. Veterinary Microbiology, 160: 151-161.

7. Sahithi K, Swetha M, Prabaharan M, Moorthi A, Saranya N, Ramasamy K, Srinivasan N, Patridge NC, Selyamugugan $N$ (2010). Synthesis and characterization of nanoscalehydroxyapatite-copper for antimicrobial activity towards bone tissue engineering applications. Journal of Biomedical Nanotechnology, 6: 333-339.

8. Witcomb LA, Green LE, Kaler J, Ul-Hassan A, Calvo-Bado LA, Medley GF, Grogono-Thomas R, Wellington EM (2014). A Longitudinal Study of the Role of Dichelobacter Nodosus and Fusobacterium Necrophorum Load in Initiation and Severity of Footrot in Sheep. Preventive Veterinary Medicine, 115: 48-55.

9. Copper. www.umm.edu/health/medical. 